\title{
Liberation War of Bangladesh: Place in the World Map
}

\author{
Ali MS ${ }^{1,2 *}$, James $\mathbf{M}^{1}$ \\ ${ }^{1}$ School of Humanities and Sociology, Nottingham Trent University, UK. \\ ${ }^{2}$ National University \\ *md.national.u@gmail.com
}

\begin{abstract}
The Bangladesh Liberation War was a revolution and armed conflict sparked by the rise of the Bengali nationalist and self-determination movement during the 1971 Bangladesh genocide in East Pakistan. This resulted in the unification of Bangladesh's People's Republic. The war began after the West Pakistani military junta launched Operation Searchlight on the night of 25 March 1971 against the citizens of East Pakistan. This sought the systematic removal of civilians, teachers, intelligentsia, religious minorities, and armed personnel from Bengali nationalism. The junta annulled the election results in 1970 and arrested Sheik Mujibur Rahman, Prime Minister-designate. The war ended on December 16, 1971, after the surrender of West Pakistan. Following nine months of war against the government of the Pakistani army, Bangladesh took its place in the world map as a sovereign country.
\end{abstract}

Keywords: Bangladesh, liberation, language, election, Pakistan

\section{INTRODUCTION}

Owing to their faith, Islam, both East and West Pakistan remained united. West Pakistan had 97 percent of Muslims and 85 percent of Muslims in East Pakistan. There were, however, some important reasons why the people of East Pakistan struggled for their independence. There were four districts in West Pakistan: Punjab, Sindh, Balochistan, and the North-West Frontier. East Pakistan was the fourth province. Through regional regulation, the West has used more energy than the East. East Pakistan accounted for 70\% of all Pakistan's exports between 1948 and 1960, while it received only 25\% of the imported money. East Pakistan had 11 fabric mills in 1948 while there were nine in the West. In 1971, the number of fabric mills in the West increased to 150, while in the East the number dropped to 26. There was also a transfer of around $\$ 2.6$ billion in wealth over time from East Pakistan to West Pakistan. Although East Pakistan had the largest population in all the provinces, it had far less political power than West Pakistan. It ultimately made East Pakistan's people rebel. The Awami League leader in East Pakistan, Sheik Mujibur Rahman, has explicitly called for more economic and political forces. Eventually, the conflict culminated in the war of independence [1].

\section{METHODOLOGY}

This study uses qualitative and quantitative approaches as well as numerous instruments for collecting data. This work is an exploratory study based on a survey that is carried out mainly from secondary data. Secondary evidence is written by academics in books and articles.

\section{FINDING AND DISCUSSION}

\section{Pakistan's State Language Movement}

After the partition of India in 1947, Bangladesh became part of Pakistan. There were two wings in Pakistan called East Pakistan and West Pakistan. But the question was what the language of the state would be? Urdu and Urdu will be both East and West Pakistan's state language, Pakistan's government declared. But East Pakistan's 
students and intellectuals protested against this statement and demanded that Bengali be Pakistan's state language. Tamaddin Mujlish began protesting against the government of Pakistan on the issue of language [2]. On 6 December 1947 East Pakistani students made a procession at Dhaka University and set up "Rastrabhasa Songram Porishad" under the direction of Tamaddin Mujlish's professor Nurul haque. Direndro Nath Dutto, member of the East Pakistan Congress Party, suggested that Bangla be added to the constituent assembly with Urdu and English on 23 February 1948. But this proposal was rejected by Liaquat Ali Khan, Pakistan's Prime Minister, and Khaza Nazimuddin, East Pakistan's chief minister [2]. Students protested the decision and made a procession at Dhaka University. They called for a strike and arrested leaders such as Shawkat Ali, Kazi Golam Mahboob, Shamsul Huq, Oli Ahad, Sheik Mujibur Rahman, Abdul Wahed and others. Mohammad Ali Jinnah, Pakistan's Governor General, arrived in East Pakistan on 19 March and proclaimed Urdu to be Pakistan's only state language in a Racecourse Ground civic reception program [3-4]. Abdul Matin set up the Language Action Committee on 11 March 1950. Khawaja Nazim Uddin came to Dhaka and no other language was listed officially, but on January 27,1952, Urdu would be Pakistan's state language [5]. Students responded rather negatively and on 30 January 1952 they gave the slogan Rastrabhasa Bangla Chai (we only want Bengali as a state language) and called strike. In February 1952, Bengali students and leaders held a major protest against the government's decision. Section 144 has been implemented by the government as a result. But on 21 February 1952, students from various colleges and leaders were gathered at Dhaka University. The students led by Abdul Matin and Gaziul Haque finally violated section 144 and shouted Rastrabhasha Bangla Chai slogans (we only want Bengali as a state language). The police fired Salam, Rafique, Jabbar, Barkot and others at the processions [6]. Bengali and Urdu were officially chosen as Pakistan's state language in 1956 after a long journey and sacrifice of life. Bangladesh's people have been celebrating Mother Language Day in February 21 since 1952. On 17 November 1999, UNESCO declared 21 February an International Mother Language Day.

\section{First Election in Pakistan's History}

The first election in Pakistan's history took place on December 7, 1970. People participated spontaneously in this highly anticipated referendum. The Awami League, headed by Sheik Mujibor Rahman, was East Pakistan's leading party. On the other hand, Pakistan Peoples Party's Zulfikar Ali Butto was the main power competitor. In this election, Awami Legue won a majority vote [7] and 160 of 162 seats in East Pakistan. Awami League had 167 seats among the selected female candidates from 313 seats in the Pakistan Assembly, and the Pakistan People's Party had 87 seats, while others had 58 seats. Awami Legue's popular vote, on the other hand, was 12,937,162, while PPP's vote was 6,148,923. Sheik Mujibur Rahman was unable to get any seat in West Pakistan, as Bhutto was unable to get any seat in East Pakistan. The president of Pakistan General Yeahya did not hand over power to Sheik Mujibur Rahman [8] despite winning the election with huge popular votes and seats. East Pakistan's friction and frustration with West Pakistan had escalated once again. West Pakistan's unjust decision was another significant step on the road to Bangladesh's war of independence.

\section{The War of Liberation}

President Yahya decided to conspire and announced in March 1971 that the assembly would be postponed. East Pakistan's people were very angry and started protests in Dhaka City. Sheik Mujibur Rahman, who by his inspirational leadership led East Pakistan's people, proclaimed a 5-day strike and called East Pakistan's noncooperation movement. East Pakistan's people certainly followed their leader. President Yahya had a curfew imposed to monitor the situation. But by making protests and signs, people broke the curfew. On 7 March 1971, Sheik Mujibur Rahman delivered a speech in the area of race (now renamed Shohrawardi Uddan). In his address, he proclaimed this battle to be our fight for liberation, this fight to be our war for freedom [9]. President Yahya Khan has appointed General Tikka Khan as East Pakistan Governor by planning to commit genocide in East Pakistan. Yahya came to East Pakistan on 15 March 1971 to meet with Sheik Mujibur Rahman and at the same time brought troops to East Pakistan. The Pakistani government tried to show its attempts to solve 
the problem, but it took time to mobilize troops in East Pakistan to commit the genocide. The Pakistani army launched genocide on the night of 25 March 197. It was called the Searchlight Operation [10-11]. All foreign journalists have been sent out of the country. The Pakistani army began the massacre by killing arrested Bengali officers in the police line of Rajarbag [12]. They targeted Dhaka University, killing students as well as teachers and items [13-14]. President Yeahya ordered that "three million of them be killed"[15]. Thirty thousand people were killed and the death squad moved to the city, East Pakistani flew out of the west Pakistani army [16]. That night, Sheik Mujibur Rahman, East Pakistan's perpetrator, was arrested. One of the genocide's objectives was to detain the leader [17]. Before being arrested, Sheik Mujibur Rahman was called upon to assemble and fight for free independent Bangladesh and his statement was transmitted from Dhaka to Chittagong and the rest of the country via EPR's transmitter [18]. Before being arrested, Sheik Mujibur Rahman was called upon to assemble and fight for free independent Bangladesh and his declaration was transmitted from Dhaka to Chittagong and the rest of the country via the EPR transmitter [18]. On March 26, 1971, the Liberation War began. Government officials, political activists, students, employees, peasants; experts, people of all ages and classes were unexpectedly involved in the war [19]. The formal officers of the Bengali army meet in Taliapara on 4 April 1971 in the headquarters of second East Bengal. There were also Colonel Mohannad Ataul Gani Osmany, Lieutenant Colonel Abdur Rob, Lieutenant Colonel Salahuddin Mohammad Reja, Major Kazi Nuruzzaman, Major Khaled Mosharaf, Major Nurul Islam, Major Shafat Jamil, Major Mainul Hossain Chowdhury and others [20]. The Bangladesh Armed Forces were created and chosen as commander-in-chief Col. MAG Osmani. This army was fighting alongside Bengali civilian Mukti Bahini [21]. On 17 April 1971, a provitional government named Mujibnagar Sorkar was formed in the People's Republic of Bangladesh. The president was Sheik Mujibur Rahman, and the vice president and acting president was Syed Nazrul Islam in the absence of Bangabandhu, and the prime minister was Tajuddin Ahmed. For each sector, Bangladesh was divided by 11 geographically separated sectors and a single sector commander [22]. There have been numerous subgroups fighting against the Pakistan army in various places, including Kader Bahini of Tangail, [23] Latif Mirza Bahini of Sirajganj, Akbar Hossain Bahini of Jhinaidah, Hemayet Bahini of Faridpur, Quddus Molla and Gafur Bahini of Barisal, Afsar Bahini of Mymensingh and Aftab Bahini of Mymensingh. Sheik Fazrul Haque Moni, Tofael Ahmed, Abdur Razzak and Sirajul Alam Khan (20) were the organizers of Mujib Bahini. India declared war on Pakistan on 3 December 1971 and joined forces in Bangladesh. Lieutenant General Jagjit Singh Aurora became the joint forces commander. After entering India, war only lasted thirteen days [24], General Niazi, head of Pakistan's armies, surrendered in the course area of the race on 16 December 1971.

\section{CONCLUSION}

Dhaka fell to the Mitro Bahini, the Mukti Bahini elite forces, and the Indian army on December 16, 1971. The defeated Pakistani General Niazi and the Indian commander General Aurora signed a "Instrument of Surrender" at 16:31 Indian Standard Time. That's how Bangladesh became united and liberated. The 16th of December is celebrated in Bangladesh as the day of victory, while the 26th of March is remembered as the day of independence. Bangladesh is making progress in all respects of sovereignty.

\section{REFERENCES}

1. Shelley, M. R.(2000), Emergence of a New Nation in a Multi-Polar World: Bangladesh, Dhaka, , pp. 111-126

2. Umar, B (1979). Purbo-Banglar Bhasha Andolon O Totkalin Rajniti. Agamee Prakashani, Dhaka. P-35

3. Choudhury, G. W. (1972). "Bangladesh: Why It Happened". International Affairs (Royal Institute of International Affairs) 48 (2): 242-249

4. Umar, B (1979). Purbo-Banglar Bhasha Andolon O Totkalin Rajniti. Agamee Prakashani, Dhaka. p. 279

5. Helal, B. A. (2003). Bhasha Andoloner Itihas (History of the Language Movement). Agamee Prakashani, Dhaka. Pp- 263-265 ISBN 984-401-523-5 
Liberation War of Bangladesh: Place in the World Map

6. Language Movement, Banglapedia - The National Encyclopaedia of Bangladesh. Asiatic Society of Bangladesh. see-

7. http://www.banglapedia.org/HT/L_0063.HTM

8. Nohlen, D.; Grotz, F. \& Hartmann, C. (2001) Elections in Asia: A data handbook, Volume I, p686

9. Iqbal, M. Z. (2009), History of the Liberation war, Dhaka

10. Haque, A. K. F., Muktishongram, p. 212-214

11. Ali, M. S. (2008), The Evidence, V-I, Dhaka, page 196

12. Bose , S.(2005) Anatomy of Violence: Analysis of Civil War in East Pakistan in 1971: Military Action: Operation Searchlight, Economic and Political Weekly , Mumbai,

13. Safiullah, K. M.(1989), Bangladesh at War, Dhaka, page 27

14. Bangladesh Genocide Archive, www.genocidebangladesh.org

15. Malik, A. (1972). The Year of the Vulture. New Delhi: Orient Longmans. pp. 79-83

16. Payne, R.(1972) , Massacre, p. 50

17. Payne, R. (1972) Massacre, p. 48

18. Iqbal, M. Z. (2009), History of the Liberation war, Dhaka

19. Salik, S.(1997), Witness to Surrender, Oxford University press, USA. page 75

20. Mohammad, B. Shwadheen Bangla Betar Kendro. pp. 36-42

21. War of Liberation, Banglapedia- The National Encyclopaedia of Bangladesh. Asiatic Society of Bangladesh. http://www.banglapedia.org/HT/W_0020.HTM

22. Jahan, R. (1973). "Bangladesh in 1972: Nation Building in a New State”. Asian Survey 13 (2): 31. doi: $10.2307 / 2642736$

23. Islam, M. R. (1974), A Tale of Millions, Adeylebros \& Co, pp226 - 231

24. Siddiki, K., Shadhinota "71, pp. 550-552

Citation: Ali MS, James M, "Liberation War of Bangladesh: Place in the World Map". American Research Journal of History and Culture, vol 6, no. 1; pp: 1-4.

Copyright (c) 2020 Ali MS, James M. This is an open access article distributed under the Creative Commons Attribution License, which permits unrestricted use, distribution, and reproduction in any medium, provided the original work is properly cited. 